\title{
Pengaruh Tingkat Pendidikan, Pelatihan Dan Pengalaman Mengajar Terhadap Profesionalisme Guru SMP Negeri Di Kabupaten Bone
}

\author{
Kasmawati \\ Universitas Muhammadiyah Bone \\ Email: awatikasma@gmail.com
}

\begin{abstract}
Abstrak. This study aims to analyze the influence of education level, training and teaching experience of teachers on the professionalism of SMPN teachers in Bone District. This research was designed using descriptive verification research type. Population in this research is all teachers of SMPN Bone Regency as many as 335 people. Determination of the number of samples is based on the slovin formula and is determined simple randomly. The number of samples based on slovin formula with a tolerance limit of $10 \%$, as many as 77 people . Data were analyzed by multiple linear regression using SPSS 23 software. The results showed that (1) the level of education, training and teaching experience had a positive and significant influence on the professionalism of SMPN teachers in Bone District and (2) The level of education was the most dominant variable affecting the professionalism of SMPN teachers in Bone District.
\end{abstract}

\section{Keyword : Education Level, Training, Teaching Experience Of Teachers, Professionalism}

\section{PENDAHULUAN}

Peranan pendidikan sekolah untuk mencerdaskan kehidupan bangsa sangat besar, sehingga peningkatan kualitas pendidikan mulai dari jenjang pendidikan terendah sampai ke jenjang pendidikan tertinggi adalah mutlak. Pemerintah yang terkait di bidang pendidikan tidak henti-hentinya mengusahakan untuk mencerdaskan bangsa melalui sekolah dasar dan sekolah menengah. Usaha-usaha tersebut meliputi pembaharuan kurikulum, peningkatan kualitas dan kuantitas tenaga pengajar, latihan wawasan pendidikan terhadap peningkatan prestasi belajar siswa.

Untuk mewujudkan tujuan tersebut, maka kemampuan guru harus dipacu guna mendukung peningkatan mutu pendidikan, dan martabat manusia Indonesia, sejalan dengan meningkatnya tuntutan kualitas dari masyarakat. Hal ini tidak dapat ditawar-tawar lagi, oleh karena itu sekolah sebagai salah satu lembaga pendidikan fomal diharapkan untuk menjawab tuntutan masyarakat. Hal itu dilakukan melalui peningkatan kinerja pelaksanaan proses pendidikan yang sedang berlangsung di dalamnya. Sekolah dituntut untuk terus berupaya secara optimal dalam memberikan pelayanan kependidikan yang bermutu dan profesional sehingga dapat menjamin kepuasan bagi siswa (pelajar).

Sampai saat ini, kelangsungan proses belajar mengajar (PBM) masih bertumpu pada guru sebagai tenaga pendidik, sehingga perannya lebih dominan. Dengan demikian, keberhasilan PBM sangat ditentukan oleh kinerja guru. Pembentukan dan pembinaan sumber daya unggul unggul pada lembaga pendidikan sangat bergantung pada kinerja guru sebagai ujung tombak penyelenggaran pendidikan. Keberhasilan guru dalam menyelenggarakan pendidikan antara lain terlihat dari perolehan nilai prestasi belajar siswa yang dibina dan tingginya profesionalisme guru.

Undang-Undang Nomor 14 tahun 2005 tentang Guru dan Dosen menyatakan bahwa" guru adalah pendidik profesional dengan tugas utama mendidik, mengajar, membimbing, mengarahkan, melatih, menilai, dan mengevaluasi peserta didik pada pendidikan anak usia dini jalur pendidikan 
formal, pendidikan dasar, dan pendidikan menengah

Danim (dalam Ahmad Barizi, 2009 : 138) menyebutkan bahwa "seorang guru dapat dikatakan profesional atau tidak, dapat dilihat dari dua perspektif. Pertama, dilihat dari tingkat pendidikan minimal dari latar belakang pendidikan untuk jenjang sekolah tempatnya menjadi guru. Kedua, penguasaan guru terhadap materi bahan ajar, mengelola proses pembelajaran, mengelola siswa, melakukan tugas-tugas bimbingan, dan kegiatan administasi lainnya".

Menurut Ahmad Barizi (2009 : 154), guru profesional merupakan produk dari keseimbangan (balance) antara penguasaan aspek keguruan dan disiplin ilmu". Latar belakang pendidikanyang dimiliki seorang guru akan berpengaruh terhadap praktek pembelajaran di kelas, seperti penentuan cara mengajar serta melakukan evaluasi (M. J.Martin Diaz, 2006 : 1177).

Kualitas pendidikan guru sangat menentukan dalam penyiapan sumber daya manusia yang handal. Menurut Peraturan Pemerintah Nomor 19 Tahun 2005 pasal 28, bahwa "pendidik harus memiliki kualifikasi akademik dan kompetensi sebagai agen pembelajaran, sehat jasmani dan rohani, serta memiliki kemampuan untuk mewujudkan tujuan pendidikan nasional". Kualifikasi akademik sebagaimana dimaksud adalah tingkat pendidikan minimal yang harus dipenuhi oleh seorang pendidik yang dibuktikan dengan ijazah dan/atau sertifikat keahlian yang relevan sesuai ketentuan perundang-undangan yang berlaku. Latar belakang pendidikan guru dapat dilihat dari dua sisi, yaitu kesesuaian antara bidang ilmu yang ditempuh dengan bidang tugas dan jenjang pendidikan. Untuk profesi guru sebaiknya juga berasal dari lembaga pendidikan guru. Guru pemula dengan latar pendidikan keguruan lebih mudah menyesuaikan diri dengan lingkungan sekolah, karena dia sudah dibekali dengan seperangkat teori sebagai pendukung pengabdiannya, sedangkan guru yang bukan Jurnal Pendidikan Mandala berlatar pendidikan keguruan akan banyak menemukan banyak masalah dalam pembelajaran.

Pelatihan guru adalah proses pendidikan yang terencana dan terprogram serta dilakukan dalam waktu yang lebih pendek bertujuan untuk mening-katkan sumber daya manusia khususnya meningkatkan pengetahuan, kemampuan dan keterampilan dalam menyiapkan atau memperbaiki kompetensi profesional guru dalam melaksanakan tugasnya di lapangan untuk kemajuan sekolahnya (Simamora, 2005: 342).

$$
\text { Pengalaman mengajar guru }
$$
merupakan salah satu faktor dalam mendukung pelaksanaan kegiatan belajar mengajar. Pengalaman mengajar yang dimiliki oleh seorang guru menjadi penentu pencapaian hasil belajar yang akan diraih oleh siswa. Pengalaman mengajar yang cukup, dalam arti waktu yang telah dilalui oleh seorang guru dalam melaksanakan tugasnya akan mendukung pencapaian hasil belajar sebagai tujuan yang akan diraih di sekolah. Pengalaman mengajar merupakan hal penting yang menjadi perhatian dalam menentukan keberhasilan pembelajaran. Guru yang mempunyai pengalaman mengajar yang memadai, secara positif akan menentukan keberhasilan proses pembelajaran, sebaliknya guru yang mempunyai pengalaman mengajar yang kurang memadai akan menghambat proses pembelajaran. Guru profesional dapat menghasilkan pendidikan yang berkualitas, yaitu dapat dicapai dengan menciptakan iklim pembelajaran yang menyenangkan, kreatif, dinamis dan dialogis (Martinis Yamin, 2009 : 20).

Penelitian Rizky Agustian Khaqqi (2009) yang menyimpulkan bahwa terdapat pengaruh tingkat pendidikan, pelatihan, dan pengalaman mengajar secara bersama-sama terhadap profesionalisme guru. Umar Said Cokro Handoko, (2008) yang juga menyimpulkan bahwa terdapat pengaruh tingkat pendidikan dan pengalaman mengajar secara bersama-sama terhadap kinerja guru. 
Abdul Malik (2006) dengan hasil penelitian yang menyimpulkan bahwa secara terpisah maupun bersama-sama, tingkat pendidikan, pengalaman mengajar, dan ketersediaan media berhubungan signifikan dengan kemampuan guru menggunakan media pembelajaran. Demikian pula Septina Galih Pudyastuti (2010) juga menyimpulkan adanya hubungan positif yang signifikan antara latar belakang pendidikan guru, pengalaman mengajar, dan pembelajaran dengan prestasi belajar siswa SMA Negeri 1 Surakarta.

Penelitian ini bertujuan untuk menganalisis pengaruh tingkat pendidikan, pelatihan, dan pengalaman mengajar guru terhadap profesionalisme guru SMPN di Kabupaten Bone.

\section{METODE PENELITIAN}

Penelitian ini didesain dengan menggunakan jenis penelitian deskriptif verifikatif. Penelitian deskriptif merupakan penelitian yang bertujuan untuk memperoleh deskripsi suatu obyek dalam hal ini adalah deskripsi terhadap variabel penelitian. Penelitian verifikatif merupakan penelitian yang bertujuan untuk mengetahui pengaruh antar variabel melalui pengujian hipotesis. Mengingat jenis penelitian yang dipilih, maka metode penelitian yang digunakan adalah descriptive survey dan explanatory survey. Penelitian ini dilaksanakan di SMPN yang ada di Kabupaten Bone. Waktu penelitian selama dua bulan yakni bulan Juni sampai dengan Agustus 2020.

Populasi dalam penelitian ini adalah seluruh guru SMPN yang ada di Kabupaten Bone sebanyak 335.Penentuan jumlah sampel didasarkan pada rumus slovin dan ditentukan secara acak sederhana. Jumlah sampel berdasarkan rumus slovin dengan batas toleransi $10 \%$, sebanyak 77 orang.

\section{HASIL DAN PEMBAHASAN \\ Hasil \\ Analisis Deskriptif Variabel}

Deskripsi variabel pada penelitian ini terdiri atas 3 (tiga) variabel independen Jurnal Pendidikan Mandala (variabel bebas) yakni tingkat pendidikan, pelatihan dan pengalaman kerja serta 1 (satu) variabel dependen (variabel terikat) yakni kinerja, sebagaimana dijelaskan berikut ini :

\section{Variabel Tingkat Pendidikan $\left(\mathrm{X}_{1}\right)$}

Tingkat pendidikan adalah pendidikan terakhir yang telah ditempuh oleh seorang guru Adapun distribusi frekuensi jawaban responden terhadap indikator pada variabel tingkat pendidikan dapat dilihat pada tabel berikut ini :

Tabel 1. Deskripsi Variabel Tingkat

\begin{tabular}{|c|c|c|c|c|c|c|}
\hline \multicolumn{7}{|c|}{ Pendidikan } \\
\hline \multirow{2}{*}{ Indikator } & \multicolumn{5}{|c|}{ Frekuensi Jawaban (orang/\%) } & \multirow[t]{2}{*}{ Rata-rata } \\
\hline & STS & TS & CS & $\mathbf{S}$ & SS & \\
\hline $\begin{array}{l}\text { Pendidikan yang berkelanjutan } \\
\text { dapat meningkatkan keahlian } \\
\text { dan pengetahuan sebagai guru }\end{array}$ & 正 & - & - & $\begin{array}{c}28 \\
36,4\end{array}$ & $\begin{array}{c}49 \\
63,6\end{array}$ & 4,63 \\
\hline $\begin{array}{l}\text { Menurut saya, pendidikan akan } \\
\text { membentuk kepribadian } \\
\text { sebagai guru }\end{array}$ & - & - & $\begin{array}{c}12 \\
15,6\end{array}$ & $\begin{array}{c}29 \\
37,7\end{array}$ & $\begin{array}{c}36 \\
46,8\end{array}$ & 4,31 \\
\hline $\begin{array}{l}\text { Menurut saya, pendidikan akan } \\
\text { membentuk pengembangan } \\
\text { wawasan }\end{array}$ & - & - & $\begin{array}{c}16 \\
20,8\end{array}$ & $\begin{array}{c}26 \\
33,8\end{array}$ & $\begin{array}{c}35 \\
45,5\end{array}$ & 4,24 \\
\hline $\begin{array}{l}\text { Menurut saya, pendidikan } \\
\text { akademis dapat meningkatkan } \\
\text { kualitas dan kemampuan untuk } \\
\text { mencapai kedudukan dan karir } \\
\text { yang lebih baik }\end{array}$ & - & - & - & $\begin{array}{c}30 \\
39,0\end{array}$ & $\begin{array}{c}47 \\
61,0\end{array}$ & 4,61 \\
\hline Rata-rata & - & - & - & - & - & 4,44 \\
\hline
\end{tabular}

Sumber : Hasil Olahan Data Primer

Tabel 1 menunjukkan bahwa indikator pertama mengenai pendidikan yang berkelanjutan dapat meningkatkan keahlian dan pengetahuan sebagai guru, proporsi terbesar adalah skor 5 atau sangat setuju sebanyak 49 orang $(63,6 \%)$; indikator kedua mengenai pendidikan akan membentuk kepribadian sebagai guru, proporsi terbesar adalah skor 5 atau sangat setuju sebanyak 36 orang $(46,80 \%)$; indikator ketiga mengenai pendidikan akan membentuk pengembangan wawasan, proporsi terbesar pada skor 5 atau sangat setuju sebanyak 35 orang $(45,5 \%)$; indikator keempat mengenai pendidikan akademis dapat meningkatkan kualitas dan kemampuan untuk mencapai kedudukan dan karir yang lebih baik, proporsi terbesar pada skor 5 atau sangat setuju sebanyak 47 orang $(61,0 \%)$.

Berdasarkan hasil perhitungan ratarata jawaban responden terhadap variabel tingkat pendidikan menunjukkan angka 4,44 yang berarti bahwa pemahaman guru SMPN 
di Kabupaten Bone mengenai tingkat pendidikan adalah sangat tinggi.

\section{Variabel Pelatihan $\left(\mathbf{X}_{2}\right)$}

Pelatihan adalah kegiatan yang dilakukan dalam meningkatkan kompetensi guru sebagai pendidik, baik di tingkat kecamatan, kabupaten/kota, provinsi, nasional maupun internasional. Adapun distribusi frekuensi jawaban responden terhadap indikator pada variabel pelatihan dapat dilihat pada tabel berikut ini:

Tabel 2. Deskripsi Variabel Pelatihan

\begin{tabular}{|c|c|c|c|c|c|c|}
\hline \multirow{2}{*}{ Indikator } & \multicolumn{5}{|c|}{ Frekuensi Jawaban (orang/\%) } & \multirow{2}{*}{$\begin{array}{c}\text { Rata- } \\
\text { rata }\end{array}$} \\
\hline & STS & TS & CS & $\mathbf{S}$ & SS & \\
\hline $\begin{array}{l}\text { Instruktur program pelatihan } \\
\text { haruslah orang yang benar-benar } \\
\text { menguasai baik secara teori maupun } \\
\text { pelaksanaan di lapangan }\end{array}$ & 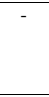 & - & - & $\begin{array}{c}52 \\
67,5\end{array}$ & $\begin{array}{l}25 \\
32,5\end{array}$ & 4,32 \\
\hline $\begin{array}{l}\text { Seorang guru seharusnya sering } \\
\text { mendapat pelatihan agar } \\
\text { profesionalisme dapat meningkat }\end{array}$ & - & - & - & $\begin{array}{c}38 \\
49,4\end{array}$ & $\begin{array}{c}39 \\
50,6\end{array}$ & 4,50 \\
\hline $\begin{array}{l}\text { Materi pelatihan yang saya ikuti } \\
\text { sangat sesuai dengan tugas sebagai } \\
\text { guru }\end{array}$ & - & - & - & $\begin{array}{c}52 \\
67,5\end{array}$ & $\begin{array}{c}25 \\
32,5\end{array}$ & 4,32 \\
\hline $\begin{array}{l}\text { Fasilitas pelatihan sangat } \\
\text { menunjang tercapainya tujuan } \\
\text { pelatihan }\end{array}$ & - & - & $\begin{array}{c}4 \\
5,2\end{array}$ & $\begin{array}{c}50 \\
64,9\end{array}$ & $\begin{array}{c}23 \\
29,9\end{array}$ & 4,24 \\
\hline $\begin{array}{l}\text { Lamanya pelatihan dapat } \\
\text { meningkatkan kemampuan }\end{array}$ & - & - & $\begin{array}{c}12 \\
15,6\end{array}$ & $\begin{array}{c}44 \\
57,1\end{array}$ & $\begin{array}{c}21 \\
27,3 \\
\end{array}$ & 4,11 \\
\hline Rata-rata & - & - & 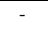 & - & - & 4,29 \\
\hline
\end{tabular}

Sumber : Hasil Olahan Data Primer

Tabel 2 menunjukkan bahwa indikator pertama mengenai instruktur program pelatihan haruslah orang yang benarbenar menguasai baik secara teori maupun pelaksanaan di lapangan, proporsi terbesar adalah skor 4 atau setuju sebanyak 52 orang $(67,5 \%)$; indikator kedua mengenai frekuensi mendapat pelatihan agar profesionalisme dapat meningkat, proporsi terbesar adalah skor 5 atau sangat setuju sebanyak 39 orang $(50,60 \%)$; indikator ketiga mengenai kesesuaian materi pelatihan dengan tugas sebagai guru, proporsi terbesar pada skor 4 atau setuju sebanyak 52 orang $(67,50 \%)$; indikator keempat mengenai Fasilitas pelatihan sangat menunjang tercapainya tujuan pelatihan, proporsi terbesar pada skor 4 atau setuju sebanyak 50 orang $(64,90 \%)$; indikator kelima mengenai lamanya pelatihan dapat meningkatkan kemampuan, proporsi terbesar pada skor 4 atau setuju sebanyak 44 orang $(57,10 \%)$.
Berdasarkan hasil perhitungan ratarata jawaban responden terhadap variabel pelatihan menunjukkan angka 4,29 yang berarti bahwa pemahaman guru SMPN di Kabupaten Bo mengenai pelatihan adalah sangat tinggi.

\section{Variabel Pengalaman Kerja $\left(\mathbf{X}_{3}\right)$}

Pengalaman mengajar adalah apa yang sudah dialami dalam mengajar yang ditandai dengan kurun waktu. Adapun distribusi frekuensi jawaban responden terhadap indikator pada variabel pengalaman mengajar dapat dilihat pada tabel berikut ini :

Tabel 3. Deskripsi Variabel Pengalaman

\begin{tabular}{|c|c|c|c|c|c|c|}
\hline \multicolumn{7}{|c|}{ Kerja } \\
\hline \multirow{2}{*}{ Indikator } & \multicolumn{5}{|c|}{ Frekuensi Jawaban (orang/\%) } & \multirow{2}{*}{$\begin{array}{l}\text { Rata- } \\
\text { rata }\end{array}$} \\
\hline & STS & TS & CS & $\mathbf{S}$ & SS & \\
\hline $\begin{array}{l}\text { Pengalaman kerja yang saya } \\
\text { miliki membantu saya } \\
\text { meningkatkan profesionalisme }\end{array}$ & 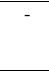 & 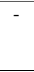 & $\begin{array}{c}6 \\
7,8\end{array}$ & $\begin{array}{c}52 \\
67,5\end{array}$ & $\begin{array}{c}19 \\
24,7\end{array}$ & 4,17 \\
\hline $\begin{array}{l}\text { Saya tidak membuang-buang } \\
\text { waktu kerja dengan kegiatan } \\
\text { lain yang tidak berkaitan dengan } \\
\text { pekerjaan }\end{array}$ & - & - & - & $\begin{array}{c}46 \\
59,7\end{array}$ & $\begin{array}{c}31 \\
40,3\end{array}$ & 4,40 \\
\hline $\begin{array}{l}\text { Saya mempunyai kemahiran } \\
\text { dalam melaksanakan tugas - } \\
\text { tugas sebagai guru }\end{array}$ & - & - & - & $\begin{array}{c}58 \\
75,3\end{array}$ & $\begin{array}{c}19 \\
24,7\end{array}$ & 4,24 \\
\hline $\begin{array}{l}\text { Pengalaman kerja yang saya } \\
\text { miliki, Membantu mengurangi } \\
\text { kesalahankesalahan yang Saya } \\
\text { lakukan pada saat saya } \\
\text { melaksanakan pekerjaan }\end{array}$ & - & - & - & $\begin{array}{c}27 \\
35,1\end{array}$ & $\begin{array}{c}50 \\
64,9\end{array}$ & 4,64 \\
\hline Rata-rata & - & - & - & - & - & 4,36 \\
\hline
\end{tabular}

Sumber : Hasil Olahan Data Primer

Tabel 3 menunjukkan bahwa indikator pertama mengenai pengalaman membantu meningkatkan profesionalisme proporsi terbesar adalah skor 4 atau setuju sebanyak 52 orang $(67,50 \%)$; indikator kedua bahwa guru tidak membuang-buang waktu kerja dengan kegiatan lain yang tidak berkaitan dengan pekerjaan, proporsi terbesar adalah skor 4 atau setuju sebanyak 46 orang $(59,70 \%)$; indikator ketiga mengenai kemahiran guru dalam melaksanakan tugas tugas sebagai guru, proporsi terbesar pada skor 4 atau setuju sebanyak 58 orang $(75,30 \%)$; indikator keempat mengenai pengalaman mengajar membantu mengurangi kesalahan-kesalahan yang dilakukan pada saat melaksanakan pekerjaan, proporsi terbesar pada skor 5 atau sangat setuju sebanyak 50 orang $(64,90 \%)$.

Berdasarkan hasil perhitungan ratarata jawaban responden terhadap variabel 
pengalaman kerja menunjukkan angka 4,31 yang berarti bahwa pemahaman guru SMPN di Kabupaten Bone mengenai pengalaman kerja adalah sangat tinggi.

\section{Variabel Profesionalisme Guru (Y)}

Profesionalisme guru adalah kualitas dan perilaku tertentu yang menjadi ciri khusus dari guru professional yaitu dengan menguasai 4 kompetensi guru agar dapat mewujudkan kinerjanya secara efektif dan efisien sebagai tenaga pendidik. Adapun distribusi frekuensi jawaban responden terhadap indikator pada variabel profesionalisme dapat dilihat pada tabel berikut ini :

Tabel 4. Deskripsi Variabel Profesionalisme Guru

\begin{tabular}{|c|c|c|c|c|c|c|}
\hline \multirow{2}{*}{ Indikator } & \multicolumn{5}{|c|}{ Frekuensi Jawaban (orang/\%) } & \multirow{2}{*}{$\begin{array}{l}\text { Rata- } \\
\text { rata }\end{array}$} \\
\hline & STS & TS & CS & $\mathbf{S}$ & SS & \\
\hline $\begin{array}{l}\text { Saya mempunyai komitmen pada } \\
\text { siswa dan proses belajarnya }\end{array}$ & - & - & $\begin{array}{c}6 \\
7,8 \\
\end{array}$ & $\begin{array}{c}46 \\
59,7\end{array}$ & $\begin{array}{c}25 \\
32,5\end{array}$ & 4,24 \\
\hline $\begin{array}{l}\text { Saya menguasai secara } \\
\text { mendalam materi pelajaran yang } \\
\text { akan diajarkan serta cara } \\
\text { mengajarkannya (metode yang } \\
\text { cocok) kepada siswa }\end{array}$ & - & - & - & $\begin{array}{c}40 \\
51,9\end{array}$ & $\begin{array}{c}37 \\
48,1\end{array}$ & 4,48 \\
\hline $\begin{array}{l}\text { Saya bertanggung jawab } \\
\text { memantau hasil belajar siswa }\end{array}$ & - & - & $\begin{array}{c}6 \\
7,8\end{array}$ & $\begin{array}{c}40 \\
51,9\end{array}$ & $\begin{array}{c}31 \\
40,3\end{array}$ & 4,32 \\
\hline $\begin{array}{l}\text { Saya mampu berpikir sistematis, } \\
\text { kritis, taktis dan strategis tentang } \\
\text { apa yang saya lakukan, dan } \\
\text { belajar dari pengalaman }\end{array}$ & - & - & - & $\begin{array}{c}48 \\
62,3\end{array}$ & $\begin{array}{r}29 \\
37,7\end{array}$ & 4,37 \\
\hline $\begin{array}{l}\text { Saya merasa merupakan bagian } \\
\text { dari masyarakat belajar dalam } \\
\text { lingkungan profesinya }\end{array}$ & - & - & - & $\begin{array}{c}38 \\
49,4\end{array}$ & $\begin{array}{c}39 \\
50,6\end{array}$ & 4,50 \\
\hline Rata-rata & - & - & - & - & - & 4,38 \\
\hline
\end{tabular}

Sumber : Hasil Olahan Data Primer

Tabel 4 menunjukkan bahwa indikator pertama mengenai komitmen pada siswa dan proses belajarnya, proporsi terbesar adalah skor 4 atau setuju sebanyak 46 orang $(59,70 \%)$; indikator kedua mengenai penguasaan secara mendalam materi pelajaran yang akan diajarkan serta cara mengajarkannya (metode yang cocok) kepada siswa, proporsi terbesar adalah skor 4 atau setuju sebanyak 40 orang $(51,9 \%)$; indikator ketiga mengenai tanggung jawab memantau hasil belajar siswa, proporsi terbesar adalah skor 4 atau setuju sebanyak 40 orang $(51,90 \%)$; indikator keempat mengenai kemampuan berpikir sistematis, kritis, taktis dan strategis tentang apa yang dilakukan, dan belajar dari pengalaman, proporsi terbesar pada skor 4 atau setuju sebanyak 48 orang $(62,30 \%)$; indikator kelima mengenai Jurnal Pendidikan Mandala perasaan sebagai bagian dari masyarakat belajar dalam lingkungan profesinya, proporsi terbesar pada skor 5 atau sangat setuju sebanyak 17 orang $(50,60 \%)$.

Berdasarkan hasil perhitungan ratarata jawaban responden terhadap variabel profesionalisme guru menunjukkan angka 4,38 yang berarti bahwa pemahaman guru SMPN di Kabupaten Bone mengenai profesionalisme guru adalah sangat tinggi.

\section{Analisis Inferensial}

Pengaruh variabel bebas yaitu tingkat pendidikan, pelatihan dan pengalaman terhadap variabel terikat yaitu profesionalisme guru (Y) diketahui melalui perhitungan regresi linear berganda. Berdasarkan hasil pengolahan data dengan menggunakan program SPSS 11.00", diperoleh Tabel berikut :

Tabel 5. Hasil Analisis Regresi Linier

\begin{tabular}{|c|c|c|c|c|}
\hline \multicolumn{5}{|c|}{ Berganda } \\
\hline Variabel & Koef.Reg & t.hitung & Probabilitas & $r^{2}$ Parsial \\
\hline $\begin{array}{c}\text { Tingkat Pendidikan } \\
\left(\mathrm{X}_{1}\right)\end{array}$ & 0,947 & 2,749 & 0,008 & 0,907 \\
\hline $\begin{array}{c}\text { Pelatihan } \\
\left(\mathrm{X}_{2}\right)\end{array}$ & 0,549 & 6,596 & 0,000 & 0,256 \\
\hline $\begin{array}{c}\text { Pengalaman Kerja } \\
\left(\mathrm{X}_{3}\right)\end{array}$ & 0,573 & 4,959 & 0,000 & 0,193 \\
\hline Konstanta & \multicolumn{2}{|c|}{ F. Ratio } & 196,477 & \\
\hline R Square & \multicolumn{2}{|l|}{ Prob. } & 0,000 & \\
\hline Multiple $\mathrm{R} \quad: 0,943$ & \multicolumn{2}{|l|}{$\mathrm{n}$} & 77 & \\
\hline
\end{tabular}

Sumber : Hasil Analisis

Tabel 5 menunjukkan hasil analisis regresi linear berganda, dimana terlihat bahwa nilai koefisien regresi terbesar adalah variabel tingkat pendidikan demikian pula dengan nilai $\mathrm{t}$ hitung dan nilai $\mathrm{r}^{2}$ parsial, yang menunjukkan bahwa pengaruh yang terbesar adalah berasal dari variabel tingkat pendidikan dengan besar pengaruh 90,7 \%, karena memiliki nilai koefisien korelasi terbesar di antara kedua variabel lain. Koefisien regresi menunjukkan besar pengaruh masing-masing variabel independent $\left(\mathrm{X}_{1}, \mathrm{X}_{2}, \mathrm{X}_{3}\right)$ terhadap variabel dependent (Y) bila besar variabel independent lain yang ada dalam model tetap. yaitu :

Persamaan regresi yang diperoleh,

$$
Y=2,520+0,947 X,+0,549 X_{2}+0,573 X_{3}
$$




\section{Pembahasan}

\section{Pengaruh Tingkat Pendidikan terhadap Profesionalisme Guru}

Variabel tingkat pendidikan $\left(\mathrm{X}_{1}\right)$ ternyata bertanda positif, ini berarti bila tingkat pendidikan ditambah akan mengakibatkan profesionalisme guru juga bertambah. Selanjutnya besarnya koefisien regresi 0,947 artinya bahwa setiap kenaikan satu unit variabel tingkat pendidikan akan mengakibatkan kenaikan sebesar 0,947 satuan profesionalisme guru, bila variabel lainnya konstan.

Koefisien determinasi parsial menjelaskan pengaruh setiap perubahan variabel independent $(\mathrm{X})$ terhadap perubahan variabel dependent (Y). Dari hasil pengolahan data menunjukkan, bahwa koefisien parsial (r) untuk variabel tingkat pendidikan sebesar 0,907. Ini berarti bahwa : variabel tingkat pendidikan dapat menjelaskan setiap variasi perubahan profesionalisme guru sebesar 0,907 dengan asumsi bahwa variabel lainnya konstan, artinya menunjukkan bahwa tingkat pendidikan memiliki korelasi yang cukup besar dengan profesionalisme guru sebesar 90,7\% dengan asumsi variabel lainnya tidak berubah.

Pengujian koefisien-koefisien regresi variabel-variabel, maka variabel tingkat pendidikan $\left(\mathrm{X}_{1}\right)$ signifikan atau tidak signifikan, dilakukan pengujian kemaknaan harga t. Pengujian tersebut dilakukan dengan uji dua arah, dengan mempergunakan taraf nyata sebesar 5\%. Hasil pengujian tersebut diperoleh thitung untuk variabel tingkat pendidikan sebesar 2,749 ; Sedangkan besarnya $t_{\text {tabel }}$ pada taraf kepercayaan $5 \%$ adalah sebesar $\pm 1,97$. Nilai-nilai tersebut di atas dapat dijelaskan bahwa secara parsial (sendiri-sendiri), variabel tingkat pendidikan berpengaruh secara signifikan terhadap profesionalisme guru SMPN di Kabupaten Bone karena nilai $t$ hitung $>$ nilai $t$ tabel. Nilai $t$ hitung dari variabel bebas tersebut berada dalam daerah penolakan $\mathrm{H}_{\mathrm{o}}$, hal ini berarti bahwa koefisien regresi variabel tingkat pendidikan tidak sama dengan 0 , dengan perkataan lain koefisien variabel tersebut adalah signifikan.

Berdasarkan hasil analisis deskriptif diketahui bahwa variabel tingkat pendidikan berada pada kategori tinggi. Hal ini didukung oleh hasil observasi yang menunjukkan bahwa peningkatan profesionlisme guru dapat dilakukan melalui peningkatan pendidikan. Hal ini sesuai dengan pendapat Danim (dalam Ahmad Barizi, 2009 : 138) yang menyatakan bahwa seorang guru dapat dikatakan profesional dilihat dari dua perspektif. Pertama, dilihat dari tingkat pendidikan minimal dari latar belakang pendidikan untuk jenjang sekolah tempatnya menjadi guru. Kedua, penguasaan guru terhadap materi bahan ajar, mengelola proses pembelajaran, mengelola siswa, melakukan tugas-tugas bimbingan, dan lain-lain. Sejalan dengan hasil penelitian Rizky Agustian Khaqqi (2009) yang menyimpulkan bahwa terdapat pengaruh tingkat pendidikan terhadap profesionalisme guru. Juga sejalan dengan PP No. 19 Tahun 2005, pasal 28 ayat 1 mengarisbawahi bahwa pendidik harus memiliki kualifikasi akademik dan kompetensi sebagai agen pembelajaran, sehat jasmani dan rohani, serta memiliki kemampuan untuk mewujudkan tujuan pendidikan nasional. Hasil penelitian ini sejalan dengan penelitian terdahulu yang dilakukan oleh Rezky (2009), Umar (2008), Abdul Malik (2006) dan Septina (2010).

\section{Pengaruh Pelatihan terhadap Profesionalisme Guru}

Variabel pelatihan $\left(\mathrm{X}_{2}\right)$ ternyata bertanda positif, ini berarti bila pelatihan bertambah akan mengakibatkan profesionalisme juga bertambah. Selanjutnya besarnya koefisien regresi 0,549 artinya bahwa setiap kenaikan satu unit variabel pelatihan akan mengakibatkan kenaikan sebesar 0,549 satuan profesionalisme guru, bila variabel lainnya konstan.

Koefisien determinasi parsial menjelaskan pengaruh setiap perubahan variabel independent $(\mathrm{X})$ terhadap perubahan variabel dependent (Y). Dari hasil pengolahan 
data menunjukkan, bahwa koefisien parsial (r) untuk variabel pelatihan sebesar 0,256. Ini berarti bahwa : variabel pelatihan dapat menjelaskan setiap variasi perubahan profesionalisme sebesar 0,256 dengan asumsi bahwa variabel lainnya konstan, artinya menunjukkan bahwa pelatihan memiliki korelasi yang cukup besar dengan profesionalisme guru sebesar $25,6 \%$ dengan asumsi variabel lainnya tidak berubah.

Pengujian koefisien-koefisien regresi variabel-variabel, maka variabel pelatihan $\left(\mathrm{X}_{2}\right)$ signifikan atau tidak signifikan, dilakukan pengujian kemaknaan harga $t$. Pengujian tersebut dilakukan dengan uji dua arah, dengan mempergunakan taraf nyata sebesar 5\%. Hasil pengujian tersebut diperoleh $t_{\text {hitung }}$ untuk variabel pelatihan sebesar 6,569 ; Sedangkan besarnya $t_{\text {tabel }}$ pada taraf kepercayaan $5 \%$ adalah sebesar $\pm 1,97$. Nilai-nilai tersebut di atas dapat dijelaskan bahwa secara parsial (sendiri-sendiri), variabel pelatihan berpengaruh secara signifikan terhadap terhadap profesionalisme guru SMPN di Kabupaten Bone karena nilai $\mathrm{t}$ hitung $>$ nilai $\mathrm{t}$ tabel. Nilai $\mathrm{t}$ hitung dari variabel bebas tersebut berada dalam daerah penolakan $\mathrm{H}_{\mathrm{o}}$, hal ini berarti bahwa koefisien regresi variabel pelatihan tidak sama dengan 0 , dengan perkataan lain koefisien variabel tersebut adalah signifikan.

Berdasarkan hasil analisis deskriptif diketahui bahwa variabel pelatihan berada pada kategori tinggi. Menurut Suyatno (2008:111), pelatihan dilakukan rangka pengembangan atau peningkatan kompetensi dalam melaksanakan tugas sebagai pendidik, baik pada tingkat kecamatan, kabupaten/kota, provinsi, nasional, maupun internasional. Bukti fisik komponen ini dapat berupa sertifikat, piagam, atau surat keterangan dari lembaga penyelenggara diklat. Sejalan dengan pendapat Jejen (2011:61) bahwa pelatihan memiliki pengaruh yang sangat signifikan terhadap efektifitas sebuah sekolah. Pelatihan memberi kesempatan kepada guru untuk mendapatkan pengetahuan, keterampilan dan sikap baru yang mengubah Jurnal Pendidikan Mandala perilakunya, yang pada akhirnya akan meningkatkan prestasi belajar siswa. Pelatihan harus sesuai dengan kebutuhan guru mengajar. Penyelenggara harus merencanakan dengan matang setiap pelatihan, mulai dari pemilihan materi, waktu, tempat, metode hingga kualitas instruktur. Hasil penelitian ini sejalan dengan penelitian terdahulu yang dilakukan oleh Rezky (2009) yang menympulkan bahwa pelathan sebagai variabel yang memperngaruhi profesionalisme guru.

\section{Pengaruh Pengalaman Kerja terhadap Profesionalisme Guru}

Variabel pengalaman kerja $\left(\mathrm{X}_{3}\right)$ ternyata bertanda positif, ini berarti bila pengalaman kerja semakin lama akan mengakibatkan profesionalisme guru juga bertambah. Selanjutnya besarnya koefisien regresi 0,573 artinya bahwa setiap kenaikan satu unit variabel pengalaman kerja akan mengakibatkan kenaikan sebesar 0,573 satuan profesionalisme kerja, bila variabel lainnya konstan.

Koefisien determinasi parsial menjelaskan pengaruh setiap perubahan variabel independent $(\mathrm{X})$ terhadap perubahan variabel dependent (Y). Dari hasil pengolahan data menunjukkan, bahwa koefisien parsial (r) untuk variabel pengalaman kerja sebesar 0,193 . Ini berarti bahwa : variabel pengalaman kerja dapat menjelaskan setiap variasi perubahan profesionalisme guru sebesar 0,193 dengan asumsi bahwa variabel lainnya konstan, artinya menunjukkan bahwa pengalaman kerja memiliki korelasi yang cukup besar dengan profesionalisme guru sebesar 58,3\% dengan asumsi variabel lainnya tidak berubah.

Pengujian koefisien-koefisien regresi variabel-variabel, maka variabel pengalaman kerja $\left(\mathrm{X}_{3}\right)$ signifikan atau tidak signifikan, dilakukan pengujian kemaknaan harga $t$. Pengujian tersebut dilakukan dengan uji dua arah, dengan mempergunakan taraf nyata sebesar 5\%. Hasil pengujian tersebut diperoleh thitung untuk variabel pengalaman kerja sebesar 4,959 ; Sedangkan besarnya $t_{\text {tabel }}$ 
pada taraf kepercayaan $5 \%$ adalah sebesar \pm 1,97. Nilai-nilai tersebut di atas dapat dijelaskan bahwa secara parsial (sendirisendiri), variabel pengalaman kerja berpengaruh secara signifikan terhadap profesionalisme guru SMPN di Kabupaten Bone karena nilai $\quad \mathrm{t}_{\text {hitung }}>$ nilai $\mathrm{t}$ tabel. Nilai $t$ hitung dari variabel bebas tersebut berada dalam daerah penolakan $\mathrm{H}_{0}$, hal ini berarti bahwa koefisien regresi variabel pengalaman kerja tidak sama dengan 0 , dengan perkataan lain koefisien variabel tersebut adalah signifikan.

Menurut Suyatn

(2008:111), pengalaman mengajar yaitu masa kerja guru dalam melaksanakan tugas sebagai pendidik pada satuan pendidikan tertentu sesuai dengan surat tugas dari lembaga yang berwenang (dapat dari pemerintah, dan/atau kelompok masyarakat penyelenggara pendidikan). Bukti fisik dari komponen ini dapat berupa surat keputusan/surat keterangan yang sah dari lembaga yang berwenang.

Unsur pengalaman dipandang sebagai akumulasi dari pengetahuan dan kehidupan dalam proses belajar. Pengalaman mengajar pada hakekatnya merupakan rangkuman dari pemahaman seseorang terhadap hal-hal yang dialami dalam mengajar, sehingga hal-hal yang dialami dapat dikuasainya, baik tentang pengetahuan, keterampilan, maupun nilai-nilai yang menyatu dalam dirinya. Apabila dalam mengajar, seorang guru menemukan hal-hal yang baru, dan hal-hal yang baru dipahaminya, maka guru tersebut akan memperoleh pengalaman kerja baru. Dengan pengalaman kerja seseorang akan banyak mendapat tambahan pengetahuan dan keterampilan tentang bidang kerjanya. Hasil penelitian ini sejalan dengan penelitian terdahulu yang dilakukan oleh Rezky (2009), Umar (2008), Abdul Malik (2006) dan Septina (2010).

\section{Pengaruh Tingkat Pendidikan, Pelatihan dan Pengalaman Kerja terhadap Profesionalisme Guru}

Berdasarkan hasil analisis regresi linear berganda, diketahui bahwa pengaruh Jurnal Pendidikan Mandala variabel-variabel bebas secara determinan sebesar $89,0 \%$ yang menunjukkan bahwa variabel tingkat pendidikan, pelatihan dan pengalaman kerja secara bersama-sama mempengaruhi variabel terikat yaitu profesionalisme guru. Sedangkan sisanya sebesar $11,0 \%$ dipengaruhi oleh variabel lain di luar model. Hal ini menunjukkan bahwa masih ada variabel lain, selain yang disebutkan di atas, yang mempengaruhi profesionalisme guru SMPN di Kabupaten Bone, yang tidak diteliti.

Hasil analisis menunjukkan bahwa variabel tingkat pendidikan, pelatihan dan pengalaman kerja secara bersama-sama berpengaruh signifikan terhadap profesionalisme guru SMPN di Kabupaten Bone. Hal ini dapat dibuktikan dari hasil perhitungan ternyata $F_{\text {hitung }}$ sebesar 196,477 , sedangkan $\mathrm{F}_{\text {tabel }}$ adalah 4,08 pada taraf kepercayaan $5 \%$. Nilai $F_{\text {hitung }}$ lebih besar daripada $F_{\text {tabel }}$, dengan perkataan lain bila $F_{\text {hitung tersebut berada di dalam daerah }}$ penolakan $\mathrm{H}_{\mathrm{o}}$, sehingga dari hasil perhitungan tersebut dapat dikatakan bahwa $\mathrm{H}_{\mathrm{o}}$ ditolak dan $\mathrm{H}_{1}$ diterima yang berarti semua variabel bebas berpengaruh secara bersama-sama terhadap variabel terikat.

Latar belakang pendidikan dan pengalaman mengajar adalah dua aspek yang mempengaruhi kompetensi seorang guru di bidang pendidikan dan pengajaran. Guru pemula dengan latar pendidikan keguruan lebih mudah menyesuaikan diri dengan lingkungan sekolah. Karena dia sudah dibekali seperangkat teori sebagai pendukung pengabdiannya. Pengalaman mengajar guru dapat diukur dari jumlah tahun lamanya ia mengajar, khususnya dalam mata pelajaran yang diampunya. Guru yang berpengalaman minimal memiliki pengalaman mengajar selama empat tahun. Profesionalisme guru merupakan hasil dari profesionalisasi yang dijalaninya secara terus menerus. Artinya semakin lama seseorang menekuni profesi sebagai seorang guru akan semakin tinggi pula tingkat keprofesionalismenya, begitu pula sebaliknya (Ahmad Barizi, 2009 : 142). 
Upaya guru mendidik, membimbing, mengajar, dan melatih anak didik bukan suatu hal yang mudah dan gampang. Pekerjaan ini membutuhkan pengalaman yang banyak dan keseriusan, di sana sini masih juga terdapat kejanggalan dan kekurangan, sang guru berupaya mengurangi sedikit mungkin kekurangan dan kesalahan di dalam mengembangkan tugas sebagai pendidik. Hasil penelitian ini sejalan dengan penelitian terdahulu yang dilakukan oleh Rezky (2009), Umar (2008), Abdul Malik (2006) dan Septina (2010).

\section{SIMPULAN}

Berdasarkan hasil analisis dan pembahasan, dapat disimpulkan bahwa :

1. Tingkat pendidikan, pelatihan dan pengalaman mengajar berpengaruh positif dan signifikan terhadap profesionalisme guru SMPN di Kabupaten Bone.

2. Tingkat pendidikan merupakan variabel yang paling dominan berpengaruh terhadap profesionalisme guru SMPN di Kabupaten Bone.

3. Tingkat pendidikan, pelatihan dan pengalaman mengajar berpengaruh positif dan signifikan secara simultan terhadap profesionalisme guru SMPN di Kabupaten Bone.

Berdasarkan kesimpulan yang menunjukkan adanya pengaruh variabel tingkat pendidikan, pelatihan dan pengalaman mengajar terhadap profesionalisme guru, maka disarankan beberapa hal yang berkaitan dengan upaya peningkatan profesionalisme yakni :

1. Pendidikan dapat ditingkatkan melalui upaya melanjutkan pendidikan ke jengjang yang lebih tinggi dan memberikan pemahaman bahwa pendidikan akan meningkatkan wawasan dan pengetahuan sebagai seorang guru.

2. Pelatihan dapat dilaksanakan secara internal maupun eksternal yang berkaitan dengan kompetensi dan kemampuan guru.

3. Pengalaman kerja dapat ditingkatkan dengan memberikan kesempatan bagi guru untuk belajar secara terus menerus dan berkesinambungan.

\section{DAFTAR PUSTAKA}

2005. Undang-Undang Republik Indonesia Nomor 14 Tahun 2005 tentang Guru dan Dosen. Jakarta: Departemen Pendidikan Nasional .2013. Uji Kompetensi dan Peniliain Kinerja Guru. Bandung: REMAJA

Agus Mulyanto. 2009. Sistem Informasi Konsep dan Aplikasi. Pustaka Pelajar.

Bagus Kisworo. (2012). Hubungan Antara Motivasi, Disiplin, dan Lingkungan 
Kerja Kengan Kinerja

Pendidik dan Tenaga Kependidikan

Sanggar Kegiatan Belajar Eks

arasidenan Semarang Jawa Tengah.

Tesis. UNY.

Barnawi dan Mohammad Arifin. 2014. Kinerja Guru Profesional:

Instrumen Pembinaan,

Peningkatan dan Penilaian. Jogjakarta: AR-RUZZ MEDIA

Cipta.

Dalyono, M. 2012. Psikologi Pndidikan. Jakarta: Rineka Cipta.

Damin, Sudarwan dan Suparno. 2009. Manajemen dan Kepemimpinan Transformasional

Kekepalasekolahan: Visi dan Strategi Sukses Era Teknologi, Situasi Krisis dan Internasional Pendidikan. Jakarta: Rineka Cipta.

Depdiknas. 2003. Undang-Undang Republik Indonesia Nomor 20 Tahun 2003 Tentang Sistem Pendidikan Nasional. Jakarta: Departemen Pendidikan Nasional.

Dwi Siswoyo, dkk. 2011. Ilmu Pendidikan. Yogyakarta: UNY Press

Hamalik, O. 2014. Kurikulum dan Pembelajaran. Jakarta: PT Bumi Aksara.

Hamalik, Oemar. Kurikulum dan Pembelajaran. Jakarta: Bumi Aksara, 2001.

Jakarta: Bumi Aksara.

Jerry H. Makawimbang (2011). Supervisi dan Peningkatan Mutu Pendidikan. Bandung, Alfabeta

Kompri. 2014. Manajemen Sekolah: Teori dan Praktik. Bandung: ALFABETA.

Mulyasa. 2012. Standar Kompetensi dan Sertifikasi Guru. Bandung: REMAJA

Munib, Achmad.2009.Pengantar Ilmu Pendidikan.Semarang: UPT MKU UNNES.
Nitisemito, Alex S. 1996. Manajemen Personalia. Cetakan Kelima. Jakarta : Ghalia Indonesia.

Nitisemito, Alex. 2000. Manajemen Personalia. Jakarta: Ghalia Indonesia POSDAKARYA. POSDAKARYA.

Priansa, Donni Juni. 2014. Kinerja dan Profesionalisme Guru. Bandung: ALFABETA.

Rachmawati, Tutik. 2013. Penilaian Kinerja Profesi Guru dan Angka Kreditnya.

Ranupandojo, Heidjrachman \& Suad Husnan. 1997. Manajemen Personalia. Yogyakarta: BPFE

Risnawatiririn. 2009. Konsep Kinerja Guru. Yogyakarta : UPP STIM YKPN

Sardiman A.M. (2009). Interaksi dan Motivasi Belajar Mengajar. Jakarta: Rajawali Pers

Saydam Gouzali. (2000). Manajemen Sumber Daya Manusia: Suatu pendekatan Mikro (dalam Tanya Jawab). Jakarta: Djambatan.

Sedarmayanti. 2001. Manajemen Perkantoran Modern. Bandung: Mandar Maju

Slameto. 2013. Belajar Dan Faktor-Faktor Yang Mempengaruhi. Jakarta: Rineka

Suhana, Cucu. 2014. Konsep Strategi Pembelajaran (Edisi Revisi). Bandung: Refika Aditama.

Suhardan, Dadang. 2010. Supervisi Profesional. Bandung:Alfa Beta. Supardi. 2013. Kinerja Guru. Jakarta: Rajawali Pers

Supardi. 2014. Aplikasi Statistika Dalam Penelitian: Konsep Statistika Yang Lebih Komprehensif. Jakarta: Prima Ufuk Semesta.

Swasta, DH, Sukotjo W, Ibnu. 2004. Pengantar Bisnis Modern. Yogyakarta: Liberty.

Syaodih Nana, Prof. Dr. 2012. Metode Penelitian Pendidikan. UPI.

Uno, Hamzah B dan Nina Lamatenggo. 2012. Teori Kinerja dan Pengukurannya. 
JUPE: Jurnal Pendidikan Mandala

Vol. 6. No. 1 Juni 2021

http://ejournal.mandalanursa.org/index.php/JUPE/index p-ISSN: 2548-5555 e-ISSN: 2656-6745

Uno, Hamzah B. 2010. Teori Motivasi dan

Pengukurannya; Analisis Di

Bidang Pendidikan. Jakarta:

Bumi Aksara. Yogyakarta:

GAVA MEDIA. 